\title{
Tensile Deformation Behavior of Ultrasonically Consolidated Laminated Ti-Al Composites at Warm Forming Temperatures
}

\author{
İrfan Kaya* \\ Department of Mechanical Engineering, Faculty of Engineering, Eskisehir Technical University, Eskisehir, Turkey \\ *irfan_kaya@eskisehir.edu.tr
}

Received: 26 September 2018

Accepted: 06 November 2018

DOI: $10.18466 /$ cbayarfbe. 464135

\begin{abstract}
The objective of the present study is to characterize the mechanical behavior of laminated metal composites (LMCs) that consist of commercially pure titanium and 1100 aluminum layers which were ultrasonically consolidated. Ultrasonic consolidation is a low temperature process used to fabricate layered solid metal structures. Tensile tests of Ti-Al laminated composites (in 3, 5, and 7 bilayer configurations) were performed at four various temperatures $\left(25^{\circ} \mathrm{C}, 100^{\circ} \mathrm{C}, 200{ }^{\circ} \mathrm{C}\right.$, and $\left.300{ }^{\circ} \mathrm{C}\right)$ using strain rate of $0.017 / \mathrm{s}$. The effect of temperature, sonotrode travel direction, and number of layers on the material behavior were discussed on the basis of uniaxial tensile test results. The ultimate tensile strength and yield strength is found to decrease with increasing temperature. In general, high strain values were obtained in $\mathrm{Y}$ samples compared to $\mathrm{X}$ samples. The maximum strain value was 0.42 at $300{ }^{\circ} \mathrm{C}$ temperature in the 5 bilayer $\mathrm{Y}$ sample.
\end{abstract}

Keywords: Laminated metal composites, ultrasonic consolidation, Ti-Al composites, ultrasonic welding, mechanical characterization, warm forming.

\section{Introduction}

In recent years, scientists have been extensively investigating composite materials instead of traditional materials due to their advantages such as less weight, more strength, and lower cost [1].

Laminated metal composites have gained popularity due to a good combination of ductility, strength and density $[2,3]$. LMCs have been fabricated by a variety of techniques, the most common of which are roll bonding, coextrusion, and ultrasonic welding. The ultrasonic consolidation (UC) method can be applied to combine most commercially available metals such as aluminium, titanium, magnesium, copper and steel [4].

Ultrasonic consolidation, a low temperature solid state additive manufacturing process, is one of the new methods used to produce laminated metal composites [57]. During this process, illustrated in Figure 1, ultrasonic energy is applied to the workpieces under a low compressive load (Normal force). The ultrasonic vibrations which are generated by ultrasonic transducers produce a friction that breaks up oxide film and contaminant on the surface allow good metal-to-metal contact. The compressive load applied to the workpieces permits the clean metal surfaces to stick together and thus the two components are joined together $[8,9]$.

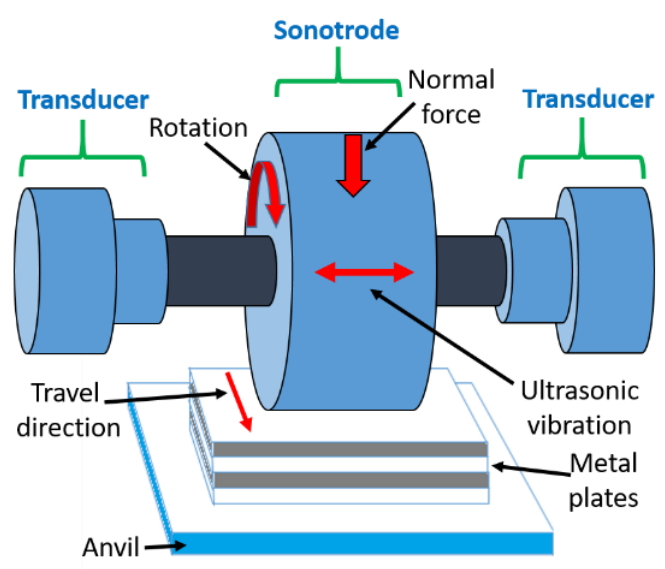

Figure 1. Schematic of the ultrasonic consolidation process.

The UC process works at temperatures much lower than the melting temperature of raw materials and enables to weld dissimilar materials [10]. Compared to other welding methods for metals, applied to low temperature and low compressive load makes this process attractive for fragile structures and heat sensitive metals to be consolidated. The low temperature ultrasonic consolidation technology has been used for welding of wide variety of dissimilar metals including Ti-Al LMCs $[11,12]$ and Al-Steel [13] to prevent the formation of detrimental intermetallic. In addition, thermally sensitive and damage intolerant fibers such as shape memory alloys (SMAs) and optical fibers can be embedded between the metallic foils by using a UC process $[14,15]$. 
Since the $\mathrm{Al}$ is light and Ti has high strength property, an examination of laminated $\mathrm{Ti}-\mathrm{Al}$ composite is of great importance for applications in the automotive and aerospace industries [16, 17]. Ultrasonically consolidated Al 1100- CP Ti laminated metal composite was investigated for armor applications due to their high strength and toughness properties by Sano et al. [18]. They reported that the CP-Ti/TiAl3/Al laminate had a higher spall strength compared to $\mathrm{CP}-\mathrm{Ti} / \mathrm{Al}$ laminate. Wolcott et al. [10] investigated the mechanical behavior of ultrasonically consolidated as-built and post-process heat treated Al 1100 / CP Ti composite samples. They found that heat treated samples showed significant increases in mechanical strength as compared to as-built samples.

In our previous work on $\mathrm{Ti}-\mathrm{Al} \mathrm{LMCs,} \mathrm{Ti-} \mathrm{Al}$ laminates were built onto a $1.527-\mathrm{mm}$-thick aluminum substrate by means of UC with different number of layer configurations were studied [19]. In the current study, Ti- Al LMCs without the thick aluminum substrate were tested under 0.017 /s strain rate.

\section{Materials and Methods}

The laminated metal composites were fabricated via ultrasonic consolidation method using titanium (Ti) and aluminum (Al 1100) plates. In this study, Ti refers to commercial pure Ti throughout this paper. The density of titanium and aluminum are; $4.5 \mathrm{~g} / \mathrm{cm}^{3}$ and $2.7 \mathrm{~g} / \mathrm{cm}^{3}$, respectively. The chemical compositions of metals that are used in the composite are shown in Table 1. The thickness of each layer is $0.127 \mathrm{~mm}$. The laminate is built up on a Ti substrate by rolling over each $\mathrm{Ti}-\mathrm{Al}$ foil with a sonotrode that produces ultrasonic vibration with low energy consumption (Figure 2). Three different numbers of bilayer (in 3, 5, and 7 bilayer configurations) were tested.

Table 1. Chemical composition of $\mathrm{Al}$ and $\mathrm{Ti}$.

\begin{tabular}{|l|l|l|l|}
\hline \multicolumn{2}{|l|}{ Aluminum 1100 } & \multicolumn{2}{l|}{$\begin{array}{l}\text { Commercial } \\
\text { Titanium }\end{array}$} \\
\hline Iron & 0.95 & Carbon & 0.002 \\
\hline Copper & $0.05-0.2$ & Titanium & 99.9221 \\
\hline Manganese & 0.05 & Iron & 0.03 \\
\hline Zinc & 0.10 & Nitrogen & 0.004 \\
\hline EA & 0.05 & Hydrogen & 0.0019 \\
\hline Aluminum & 99.00 & $*$ & $*$ \\
\hline
\end{tabular}

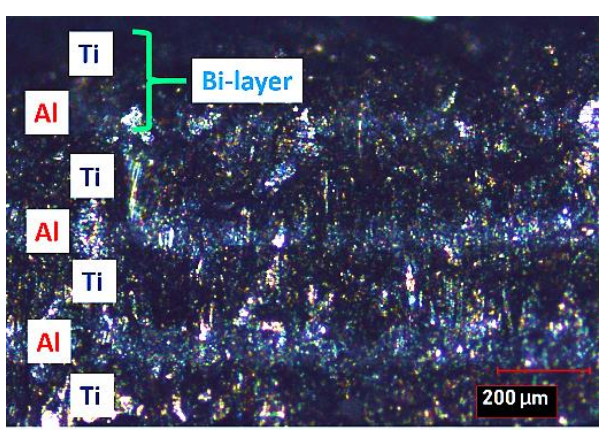

Figure 2. Ti-Al laminated composite (3 bilayer sample).
The dimensions of tensile coupons are given in Figure 3. The tensile coupons were prepared in two directions: (1) sonotrode travel direction is perpendicular to the pulling direction (named X), and (2) sonotrode travel direction is parallel to pulling direction (named Y) (Figure 3). The 3, 5 , and 7 bi-layers with thickness of $0.889,1.397$ and 1.905 , respectively, were used for tensile test.

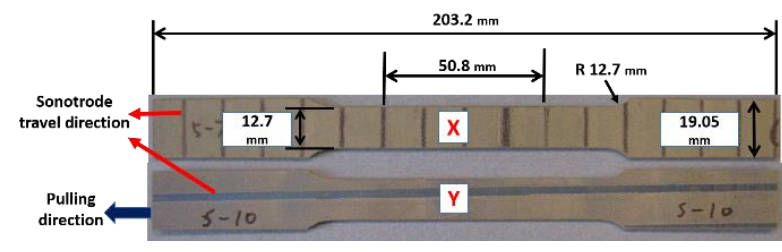

Figure 3. Dimensions of the tensile test samples.

A $10 \mathrm{kN}$ electromechanical MTS tensile testing machine equipped with a furnace was used for testing the mechanical properties of laminated metal composite materials (Figure 4). The specimens were held by the grippers. The temperature of the sample was measured with K-type thermocouple attached at the center of the sample. Ti-Al LMC coupons were drawn to the single axis at a constant speed and at a constant temperature on the warm tensile test device. For each testing condition, three specimens were used to ensure the repeatability of the results.

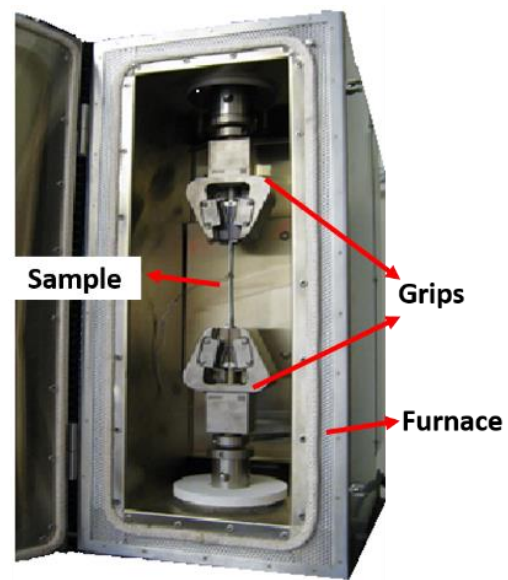

Figure 4. Tensile testing machine equipped with a furnace.

\section{Results and Discussion}

Figure 5 shows the tensile stress-strain responses of laminated metal composites in different directions ( $\mathrm{X}$ and Y) at selected test temperatures. Figure 5(a) through (c) show the tensile test results for $\mathrm{X}$ samples while Figure $5(d)$ through (f) show the results of Y samples. The test coupons were loaded at four test temperatures $\left(25^{\circ} \mathrm{C}, 100\right.$ ${ }^{\circ} \mathrm{C}, 200{ }^{\circ} \mathrm{C}$, and $300{ }^{\circ} \mathrm{C}$ ) at a strain rate of $0.017 / \mathrm{s}$. The flow stress initially increases linearly with increasing strain up to the yield strength (YS). This linear section is not included in the graphs. Then, flow stress continues to increase non-linearly with increasing strain up to ultimate tensile strength (UTS) which the last stress level is shown 
in Figure 5. The YS and UTS are significant factors to characterize the material properties.

In Figure 5, it is seen that the ductility increased slightly with the temperature. The strain values were $0.24,0.25$, 0.31 , and 0.32 at $25{ }^{\circ} \mathrm{C}, 100{ }^{\circ} \mathrm{C}, 200{ }^{\circ} \mathrm{C}$, and $300{ }^{\circ} \mathrm{C}$, respectively, for 3 bilayer $\mathrm{X}$ sample (Figure 5(a)). The strain values were $0.26,0.3,0.35$, and 0.35 at $25^{\circ} \mathrm{C}, 100$ ${ }^{\circ} \mathrm{C}, 200{ }^{\circ} \mathrm{C}$, and $300{ }^{\circ} \mathrm{C}$, respectively, for 3 bilayer $\mathrm{Y}$ sample (Figure 5(d)). In 5 bilayer $\mathrm{X}$ sample, the strain value was 0.25 at $25^{\circ} \mathrm{C}$ and increased to 0.40 at $300{ }^{\circ} \mathrm{C}$ (Figure 5(b)). These values were 0.28 and 0.42 at $25^{\circ} \mathrm{C}$ and $300{ }^{\circ} \mathrm{C}$, respectively, for 5 bilayer Y sample (Figure $5(\mathrm{e})$ ). The strain values were 0.28 and 0.41 at test temperature of $25{ }^{\circ} \mathrm{C}$ and $300{ }^{\circ} \mathrm{C}$, respectively, for 7 bilayer X sample (Figure 5(c)). The strain values of 7 bilayer $\mathrm{Y}$ samples were 0.26 and 0.37 at $25^{\circ} \mathrm{C}$ and 300 ${ }^{\circ} \mathrm{C}$, respectively (Figure 5(f)).

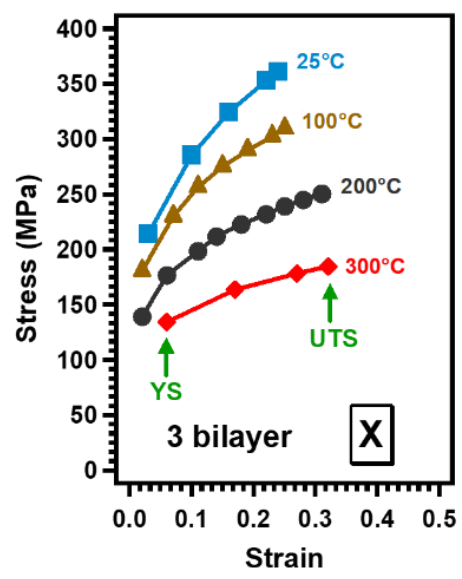

(a)

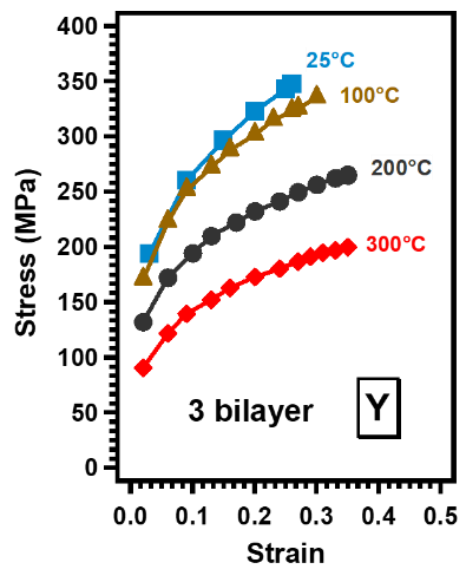

(d)

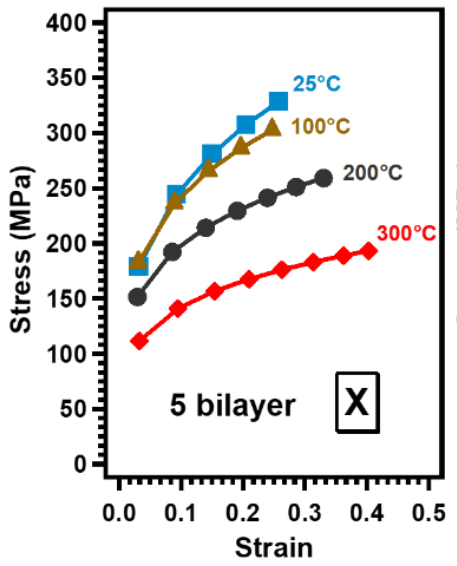

(b)

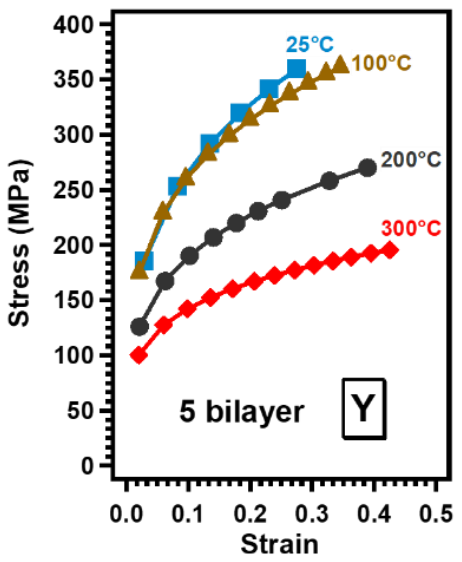

(e)

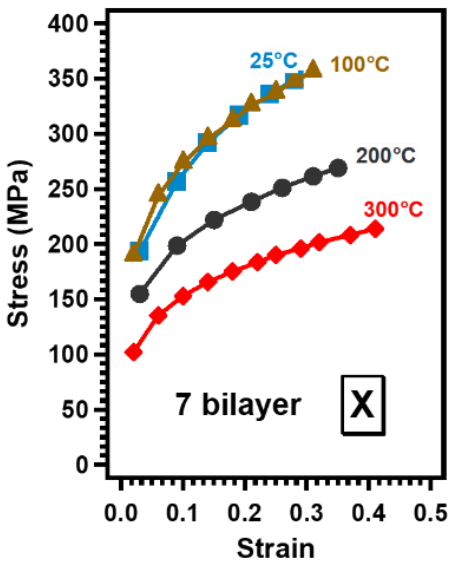

(c)

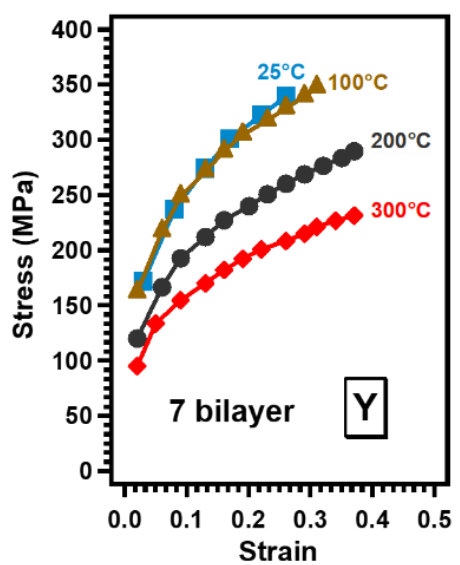

(f)

Figure 5 Stress-strain curves of laminated metal composites obtained from tensile tests; (a to c) X samples, and (d to f) Y samples.

Figure 6 shows the UTS, YS, and strain as a function of the number of bilayer along the $\mathrm{X}$ and $\mathrm{Y}$ samples at four test temperatures. UTS, YS, and strain were extracted from Figure 5 and plotted in Figure 6.

As shown in Figure 6 (a) and Figure 6 (b), the UTS and YS both decrease with increasing test temperature. In the 3 bilayer $\mathrm{X}$ sample, increasing the temperature from 25 ${ }^{\circ} \mathrm{C}$ to $300{ }^{\circ} \mathrm{C}$ decreased the UTS value from $361 \mathrm{MPa}$ to $185 \mathrm{MPa}$ and increased the strain value from 0.24 to 0.32 . The stress was reduced by almost half with the temperature increased. The decrease in the UTS with increasing test temperature (from $25{ }^{\circ} \mathrm{C}$ to $300{ }^{\circ} \mathrm{C}$ ) is greatest for the 3 bilayer $\mathrm{X}$ sample $(176 \mathrm{MPa})$ and least for the 7 bilayer Y sample (107 MPa). The decrease in the YS with increasing test temperature (from $25{ }^{\circ} \mathrm{C}$ to $\left.300{ }^{\circ} \mathrm{C}\right)$ is greatest for the 3 bilayer $\mathrm{Y}$ sample $(103 \mathrm{MPa})$ and least for 5 bilayer $\mathrm{X}$ sample $(67 \mathrm{MPa})$. Examining the results in Figure 6(a) through (c), it is seen that UTS did not significantly change with increasing number of bilayers for both $\mathrm{X}$ and $\mathrm{Y}$ samples above the $100{ }^{\circ} \mathrm{C}$ test temperature. The UTS values were $251 \mathrm{MPa}, 259 \mathrm{MPa}$, and $269 \mathrm{MPa}$ for 3 bilayer, 5 bilayer, and 7 bilayer samples, respectively, at $200{ }^{\circ} \mathrm{C}$ test temperature for $\mathrm{X}$ samples, while these values were $265 \mathrm{MPa}, 270 \mathrm{MPa}$, and $289 \mathrm{MPa}$ for 3 bilayer, 5 bilayer, and 7 bilayer at test temperature of $200{ }^{\circ} \mathrm{C}$, respectively, for Y samples.

In general, higher YS values were obtained in the $\mathrm{X}$ samples than in the $\mathrm{Y}$ samples. In $\mathrm{X}$ samples, the YS 
values were $139 \mathrm{MPa}, 152 \mathrm{MPa}$, and $155 \mathrm{MPa}$ for 3 bilayer, 5 bilayer, and 7 bilayer, respectively, at $200{ }^{\circ} \mathrm{C}$ test temperature. In Y samples, the YS values were 132 $\mathrm{MPa}, 126 \mathrm{MPa}$, and $120 \mathrm{MPa}$ for 3 bilayer, 5 bilayer, and 7 bilayer, respectively, at $200^{\circ} \mathrm{C}$ test temperature.

The difference between UTS and YS decreases with increasing test temperatures. The small difference means high YS/UTS ratio. Especially YS/UTS value is very high for the 3 bilayer sample at $300{ }^{\circ} \mathrm{C}$ compared to other samples. The detection of initial signs of failure becomes difficult compared to other conditions.

In Figure 6 (c), it is seen that the strain values of $Y$ samples were higher than the strain values of $\mathrm{X}$ samples. In 3 bilayer and 5 bilayer, Y samples exhibited greater elongation than the $\mathrm{X}$ samples at all temperatures. However, looking at the results for the 7 bilayer, the elongation values for $\mathrm{X}$ and $\mathrm{Y}$ samples are close to each other at all temperatures, except $300^{\circ} \mathrm{C}$. It was 0.28 and 0.26 at $25^{\circ} \mathrm{C}$ and 0.31 and 0.31 at $100{ }^{\circ} \mathrm{C}$ and 0.35 and 0.37 at $200{ }^{\circ} \mathrm{C}$ along the $\mathrm{X}$ and $\mathrm{Y}$ samples, respectively.

In the $\mathrm{X}$ samples, elongation increased with increasing number of bilayer. Strains were $0.24,0.25$, and 0.28 at 25 ${ }^{\circ} \mathrm{C}$ and $0.32,0.4$, and 0.41 at $300{ }^{\circ} \mathrm{C}$ along the 3,5 , and 7 bilayer samples, respectively. This increase did not appear in the Y samples.

In general, the enhanced elongation becomes significant at $200{ }^{\circ} \mathrm{C}$. The strain values of 3 bilayer and 5 bilayer were 0.31 and 0.33 at $200{ }^{\circ} \mathrm{C}$, respectively, for $\mathrm{X}$ samples. At the same test temperature, the strain values of 3 and 5 bilayers were 0.35 and 0.39 , respectively, for Y specimens.

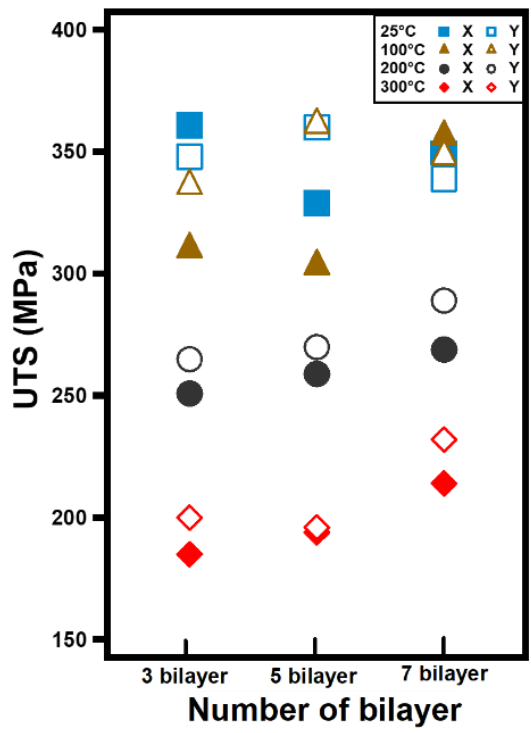

(a)

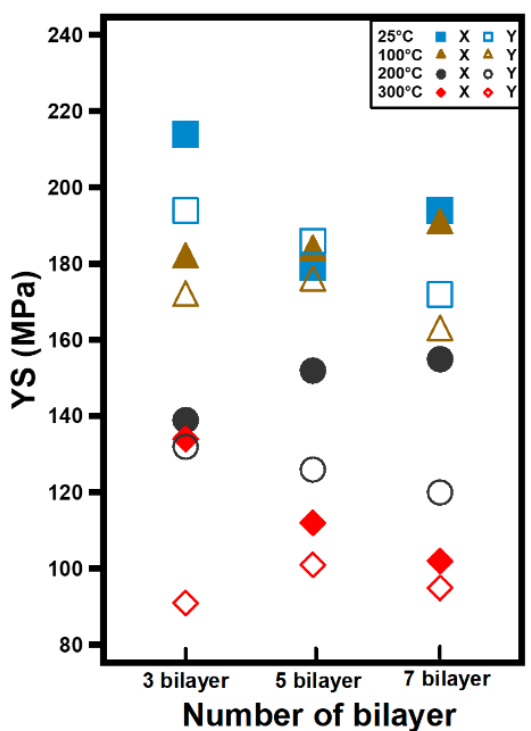

(b)

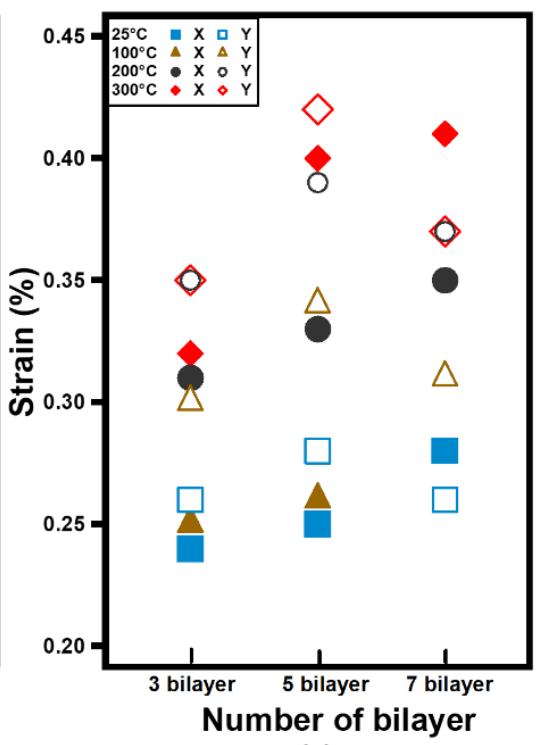

(c)

Figure 6 Stress-strain curves of laminated metal composites obtained from tensile tests; (a to c) X samples, and (d to f) Y samples.

Table 2. UTS, YS and strain values of laminated metal composites.

\begin{tabular}{|c|c|c|c|c|c|c|c|c|c|c|c|c|c|c|c|c|c|c|}
\hline \multirow[b]{3}{*}{$\begin{array}{l}\text { Temp. } \\
\left({ }^{\circ} \mathrm{C}\right)\end{array}$} & \multicolumn{6}{|c|}{3 bilayer } & \multicolumn{6}{|c|}{5 bilayer } & \multicolumn{6}{|c|}{7 bilayer } \\
\hline & \multicolumn{3}{|c|}{$x$} & \multicolumn{3}{|c|}{$Y$} & \multicolumn{3}{|c|}{$x$} & \multicolumn{3}{|c|}{$Y$} & \multicolumn{3}{|c|}{$x$} & \multicolumn{3}{|c|}{$Y$} \\
\hline & $\begin{array}{l}\text { UTS } \\
\text { (MPa) }\end{array}$ & $\begin{array}{l}\text { YS } \\
\text { (MPa) }\end{array}$ & $\begin{array}{l}\text { Strain } \\
(\%)\end{array}$ & \begin{tabular}{|l} 
UTS \\
(MPa)
\end{tabular} & \begin{tabular}{|l} 
YS \\
(MPa)
\end{tabular} & $\begin{array}{l}\text { Strain } \\
(\%)\end{array}$ & \begin{tabular}{|l|} 
UTS \\
(MPa)
\end{tabular} & \begin{tabular}{|l} 
YS \\
(MPa)
\end{tabular} & $\begin{array}{c}\text { Strain } \\
(\%)\end{array}$ & \begin{tabular}{|c|} 
UTS \\
(MPa)
\end{tabular} & \begin{tabular}{|c|} 
YS \\
(MPa)
\end{tabular} & $\begin{array}{c}\text { Strain } \\
(\%)\end{array}$ & \begin{tabular}{|l} 
UTS \\
(MPa)
\end{tabular} & $\begin{array}{c}\text { YS } \\
\text { (MPa) }\end{array}$ & $\begin{array}{l}\text { Strain } \\
(\%)\end{array}$ & $\begin{array}{l}\text { UTS } \\
\text { (MPa) }\end{array}$ & \begin{tabular}{|c|} 
YS \\
(MPa)
\end{tabular} & $\begin{array}{c}\text { Strain } \\
(\%)\end{array}$ \\
\hline 25 & 361 & 214 & 0.24 & 348 & 194 & 0.26 & 329 & 179 & 0.25 & 360 & 186 & 0.28 & 349 & 194 & 0.28 & 339 & 172 & 0.26 \\
\hline 100 & 310 & 181 & 0.25 & 336 & 171 & 0.3 & 303 & 183 & 0.26 & 361 & 175 & 0.34 & 356 & 190 & 0.31 & 348 & 162 & 0.31 \\
\hline 200 & 251 & 139 & 0.31 & 265 & 132 & 0.35 & 259 & 152 & 0.33 & 270 & 126 & 0.39 & 269 & 155 & 0.35 & 289 & 120 & 0.37 \\
\hline 300 & 185 & 134 & 0.32 & 200 & 91 & 0.35 & 194 & 112 & 0.4 & 196 & 101 & 0.42 & 214 & 102 & 0.41 & 232 & 95 & 0.37 \\
\hline
\end{tabular}

According to the results shown in Table 2, within all materials, 5 bilayer $\mathrm{Y}$ sample showed maximum elongation. The maximum strain value was 0.42 at 300 ${ }^{\circ} \mathrm{C}$ test temperature at $0.017 / \mathrm{s}$ strain rate for 5 bilayer sample (Figure 6(c)). The effect of the test temperature 
on the elongation was observed in at most 5 bilayers. Strain values increased by about 0.15 for 5 bilayer $X$ and Y samples. According to Figure 6(c), the highest strain value of 0.35 was reached at $200{ }^{\circ} \mathrm{C}$ and $300{ }^{\circ} \mathrm{C}$ test temperatures for $\mathrm{Y}$ sample while the highest value was 0.32 for $\mathrm{X}$ sample at $300{ }^{\circ} \mathrm{C}$ in 3 bilayer samples.

\section{Conclusion}

This paper has made an attempt to study the tensile behavior of ultrasonically consolidated Ti-Al composites $(3,5$ and 7 bilayers $)$ at four different temperatures $\left(25^{\circ} \mathrm{C}\right.$, $100{ }^{\circ} \mathrm{C}, 200{ }^{\circ} \mathrm{C}$, and $300{ }^{\circ} \mathrm{C}$ ). The conclusions drawn from the study are as follows:

- The uniaxial tensile strength of Ti-Al LMCs decreased with increasing temperature. The ultimate tensile strength showed more pronounced decrease after $100{ }^{\circ} \mathrm{C}$ temperature.

- Number of bilayers did not significantly affect the ultimate tensile strength value above the $100{ }^{\circ} \mathrm{C}$ test temperature.

- In general, higher yield strength values were obtained in the $\mathrm{X}$ samples than in the $\mathrm{Y}$ samples.

- As a result of the temperature increase, the YS and ultimate tensile strength values converge to each other.

- The effect of the test temperature on the elongation was observed in at most 5 bilayers.

- When the temperature increased from $100{ }^{\circ} \mathrm{C}$ to 200 ${ }^{\circ} \mathrm{C}$, there was an obvious increase in elongation. The maximum elongation $(0.42)$ was observed in 5 bilayer $\mathrm{Y}$ sample at $300^{\circ} \mathrm{C}$. The obtained highest elongation of 5 bilayer $\mathrm{Y}$ sample needs further investigation to reveal the detailed explanation.

\section{Acknowledgement}

First author acknowledges the support from Anadolu University (Grant \#. BAP-1705F248 and \#.BAP1706F382).

\section{References}

1. Mangalgiri, P.D., Composite materials for aerospace applications, Bulletin of Materials Science, 1999, 22(3), 657-664

2. Lesuer, D.R., Syn, C.K., Sherby, O.D., Wadsworth, J., Lewandowski, J.J., Hunt, W.H., Mechanical behaviour of laminated metal composites, International Materials Reviews, 1996, 41(5), 169-197.

3. Sherby, O.D., Lee, S., Koch, R., Sumi, T., Wolfenstine, J., Multilayered composites based on ultrahigh carbon steel and brass, Materials and Manufacturing Processes, 1990, 5(3), 363-376.

4. Daniels, H., Ultrasonic welding, Ultrasonics, 1965, 3(4), 190-196.
5. Obielodan, J., Ceylan, A., Murr, L.E., Stucker, B.E., Multi-material bonding in ultrasonic consolidation, Rapid prototyping journal, 2010, 16(3), 180-188

6. Kong, C., Soar, R., Dickens, P., Characterisation of aluminium alloy 6061 for the ultrasonic consolidation process, Materials Science and Engineering: A, 2003, 363(1-2), 99-106.

7. White, D.R., Ultrasonic Consolidation of Aluminum Tooling, Advanced materials \& processes, 2003, 161(1), 64-65

8. Yang, Y., Stucker, B.E., Janaki Ram, G.D., Mechanical Properties and Microstructures of $\mathrm{SiC}$ Fiber-reinforced Metal Matrix Composites Made Using Ultrasonic Consolidation, Journal of Composite Materials, 2010, 44(26), 3179-3194.

9. Zhang, C.S., Li, L., A coupled thermal-mechanical analysis of ultrasonic bonding mechanism, Metallurgical and Materials Transactions B, 2009, 40(2), 196-207.

10. Wolcott, P.J., Sridharan, N., Babu, S.S., Miriyev, A., Frage, N., Dapino, M.J., Characterisation of Al-Ti dissimilar material joints fabricated using ultrasonic additive manufacturing, Science and Technology of Welding and Joining, 2016, 21(2), 114-123.

11. Hopkins, C.D., Dapino, M.J., Fernandez, S.A., Statistical Characterization of Ultrasonic Additive Manufacturing Ti/Al Composites, Journal of Engineering Materials and Technology, 2010, 132(4), 041006-041006-9.

12. Sridharan, N., Wolcott, P., Dapino, M., Babu, S.S., Microstructure and texture evolution in aluminum and commercially pure titanium dissimilar welds fabricated using ultrasonic additive manufacturing, Scripta Materialia, 2016, 117, 1-5.

13. Obielodan, J.O., Janaki Ram, G.D., Stucker, B.E., Taggart, D.G., Minimizing Defects Between Adjacent Foils in Ultrasonically Consolidated Parts, Journal of Engineering Materials and Technology, 2009, 132(1), 011006-011006-8.

14. Kong, C., Soar, R., Fabrication of metal-matrix composites and adaptive composites using ultrasonic consolidation process, Materials Science and Engineering: A, 2005, 412(1-2), 12-18.

15. Kong, C., Soar, R., Dickens, P., Ultrasonic consolidation for embedding SMA fibres within aluminium matrices, Composite Structures, 2004, 66(1-4), 421-427.

16. Du, Y., Fan, G., Yu, T., Hansen, N., Geng, L.,Huang, X., Laminated Ti-Al composites: Processing, structure and strength, Materials Science and Engineering: A, 2016, 673, 572-580.

17. Lu, Z., Wei, N., Li, P., Guo, C., Jiang, F., Microstructure and mechanical properties of intermetallic Al3Ti alloy with residual aluminum, Materials \& Design, 2016, 110, 466-474.

18. Army Research Laboratory, Microstructural and mechanica behavior characterization of ultrasonically consolidated titaniumaluminum laminates. http://www.dtic.mil/dtic/tr/fulltext/u2/a499565.pdf, $\quad 2009$ (accessed 03.10.2018).

19. Kaya, İ., Cora, Ö.N., Acar, D., Koç, M., On the Formability of Ultrasonic Additive Manufactured Al-Ti Laminated Composites, Metallurgical and Materials Transactions A, 2018, 1-14. 